of significant differences to $4 \mathrm{~h}$ in cell phagocytic capacity in vivo. MCN treatment decreased the NFN and increased the CFU values in vaccinated mice reaching control values, and this effect was reversed when MCN was inactivated. These results highlight the contribution of NETs is as an important cellular defense mechanism in anti-plague immunity.

5.14

doi: 10.15789/2220-7619-2018-4-5.14

\section{HLA GENE POLYMORPHISM IN PERSONS} VACCINATED AGAINST PLAGUE

O.M. Kudryavtseva, T.N. Shchukovskaya, N.I. Mikshis, A.Yu. Goncharova, S.N. Klyueva, S.A. Bugorkova

Russian Research Anti-Plague Institute "Microbe", Saratov, Russia

The live-attenuated vaccine based on the Yersinia pestis strain EV NIIEG is still in use in the Russian Federation for the protection of people living in territories endemic for plague and provides a high degree of efficacy, but fluctuations in individual values of adaptive immunity in response to vaccination necessitate the establishment of genes that control the variability of the immune response. Human Leukocyte Antigen (HLA) genes play a decisive role in this process. In this study the distribution of HLA genes in people, vaccinated EV NIIEG live vaccine and living in the Caspian sand plague focus (Kalmykia and from Astrakhan), was investigated for their connection of HLA genes with indicators of immunity factors. The study involved 120 people. HLA gene typing was performed by multiplex PCR. Production of cytokines was determined by enzyme immunoassay. Statistical processing of the results was performed using the program "Statistica" 10.0. We determined that HLA-DRB1 alleles were more often in both regions $* 04(20-21 \%), * 03(18 \%), * 07(15-16 \%)$ and $* 01(10-15 \%)$. No significant difference was found, as well as in the reaction of cytokines in the inhabitants of both regions. The difference in the distribution of variants of the gene DRB1 and DQA1 was found in residents of the Lagan district of Kalmykia - the predominance of allele group DRB1*04 (40\%) compared to DRB1*03(10\%). The dynamics of cytokine production also varied by region of residence. 1 month after the vaccination, the levels of TNF $\alpha$ and IL-10 production increased in the residents of the Lagan district, and the inhabitants of the Black Soil district showed their decrease. The difference in cytokine production among residents of the Lagan district may be related to the special distribution of haplotypes of HLA.

The results show that the polymorphism of HLA genes has an effect on the level of cytokine secretion in response to the vaccinated EV NIIEG live vaccine. Further study of genes regulating the production of immune factors, will improve the understanding of the mechanisms of the immune response after vaccination, as well as contribute to the prediction of immunogenicity and effectiveness of vaccine products developed.

5.15

doi: 10.15789/2220-7619-2018-4-5.15

\section{WHOOPING COUGH - AN UNDERESTIMATED} "ADULT" INFECTION

\section{N.N. Kurova}

St. Petersburg Pasteur Institute, St. Petersburg, Russia

Whooping cough is traditionally considered as a childhood infection. However, studies carried out in several countries, have shown that the actual incidence among adults is $10-100$-fold higher than official statistics. Adults and older siblings become sources of pertussis for infants.
The aim of this study was to determine the true incidence of whooping cough in the adult population of St. Petersburg. The objective was to estimate the circulation of pertussis causative agent among the adult population of St. Petersburg (age $\geq 18$ years), using antibody level to pertussis toxin as a marker of disease/natural booster in the last 12 months.

We examined 538 adults who applied to the medical center for blood tests for diagnosis of chronic nonpulmonary diseases, aged 18 to 82 years (mean age 41.2 years), 333 women, 205 men. Method: ELISA for the detection of antibodies to pertussis toxin (IgG, IgA). The IgG value $\geq 40 \mathrm{IU} / \mathrm{ml}$ was defined for categorization of whooping cough or contact with the patient during the last 12 months; including the IgG level $\geq 40 \mathrm{IU} / \mathrm{ml}$ in combination with a positive IgA level $(\geq 12 \mathrm{IU} / \mathrm{ml})$ or $\mathrm{IgG} \geq$ $100 \mathrm{IU} / \mathrm{ml}$ with any IgA value for categorization of current or recent infection.

Anti-pertussis toxin $\mathrm{IgG}$ were detected in 87 patients (16.2\% of those examined), including 27 patients $(5.1 \%)$ with serological markers of recent infection. The proportion of seropositive persons was highest in the groups of 1829 and $30-39$ years (21.4 and $19.9 \%$, respectively), followed by a decrease to $5.7 \%$ in the 50-59 age group; in the group of 60 years and older, the proportion increased to $13.9 \%$. The proportion of patients with serological markers of recent infection was highest in the group of $18-29$ years too $(6.4 \%)$.

The wide involvement of adults in the epidemic process of whooping cough in St. Petersburg was revealed, particularly in the age group 18-39 years. Attention is drawn to the increase in the proportion of seropositive patients older than 60 years due to the increasing risk of a more severe and complicated course of the disease in this age group. It is necessary to include pertussis as a cause of prolonged cough in the training cycles of the post-graduated medical education for the "adult" physicians.

5.16 doi: $10.15789 / 2220-7619-2018-4-5.16$

\section{CHARACTERISTICS OF A MOBILE LABORATORY FOR MONITORING AND DIAGNOSTICS DURING EPIZOOTOLOGICAL INVESTIGATION IN THE MONGOLIAN PART OF THE TRANSBOUNDARY SAILUGEM PLAGUE FOCUS}

E.N. Rozhdestvensky ${ }^{1}$, E.G. Tokmakova ${ }^{2}$, S.A. Kosilko ${ }^{2}$, V.M. Korzun ${ }^{2}$, I.L. Grigoreva ${ }^{1}$, S.S. Akulova ${ }^{1}$, S.V. Balakhonov ${ }^{2}$

${ }^{1}$ Altai Antiplague Station of Rospotrebnadzor, Gorno-Altaisk, Russia; ${ }^{2}$ Irkutsk Antiplague Research Institute of Rospotrebnadzor, Irkutsk, Russia

Spread of Yersinia pestis of the basic subspecies in the Russian part of the transboundary Sailugem natural plague focus and the followed epidemiological complications required the assessment of the situation in the Mongolian part of the focus. So, since 2017 joint Russian-Mongolian epizootological examinations are performed at its frontier sites. Peculiarities of the investigations in 2018 were connected with using of a mobile laboratory for monitoring and diagnostics (MLMD) on the basis of "KAMAZ" lorry that appeared in the Altai Antiplague Station in 2017.

MLMD autonomy permitted to conduct researches in immediate proximity from the examined sites with daily delivery of the material. Combing, dissection, sampling were performed in a specially equipped jurt. Two samples were taken from the whole mammal carcasses: liver and spleen pieces were placed in a plastic test tube for homoge- 